\title{
Summer and Fall Visitors
}

By MRS. H. RODENBERG, Kinlock, Sask.

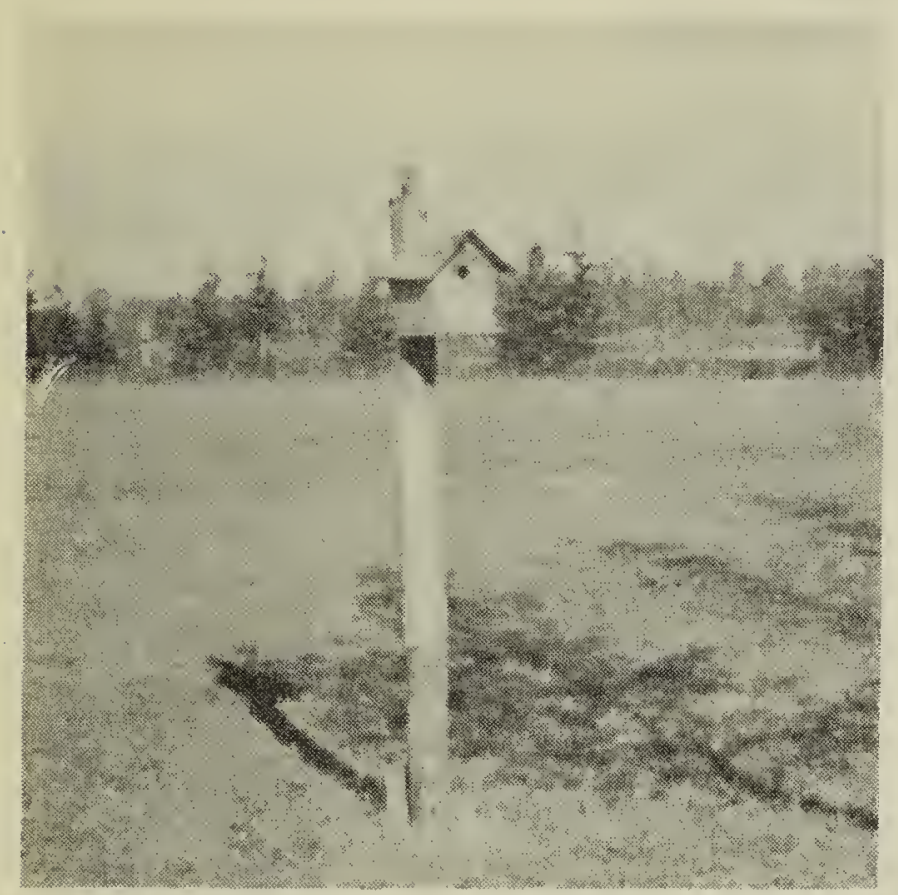

This has been a very good summer for our birds.

The Martins came April 17th, twelve days earlier than usual. We had seventeen pair of them. The other three rooms in the twentyroom house were taken over by sparrows. The Martins left for the south, August 23rd.

On April 25th the Tree Swallows arrived. Three pair built in houses in our yard. On May 24th we had a pleasant surprise as a large flock of Swift Swallows came to look for a place to build. Several nests were started but for some reason the the birds couldn't make the mud stick. They would get them about half finished when down they fell. Finally we decided to put up wedges about three inches wide by six inches long. No sooner had they been placed when the swallows started building on them. How busy they were! It took them about ten days to complete their nests. One pair raised two sets of young.

Two pair of Robins built within a short distance from our house. There is nothing I like better than to wake up early in the morning and hear the robins sing.

There were a great number of Purple Finches and White-crowned sparrows here all summer. I never did find their nests, but they could not have been very far away as we saw them every day.

Ruby-throated $\mathrm{Hu}$ m m i $\mathrm{ng}$ birds visited my delphiniums outside our windows several times a day. Once, while I was watching them, the female lit on the window sill and sat there a full minute or more. I have quite often seen them sitting on my clothesline.

There seemed to be more Bluebirds around too, but as yet they haven't built in any of my birdhouses. However they often come and fed around the buildings.

About the first of October, while I was painting the birdhouse, pictured here, two Bluebirds came and sat in the maple tree, near by. They didn't seem to mind my being there at all as they remained a long time, whistling their mellow notes.

Today is a lovely fall day. There are Juncos and Chickadees everywhere. There are also four Blue Jays chattering away in some trees near by. The Canada Jays are also coming near the house again, looking for scraps. Both Blue Jays and Canada Jays come to my feeding tray in our veranda all winter.

\section{Misrepresentation}

Mrs. John Hubbard, Grenfell, Sask.

Either he got the story wrong or he was three months late for the Osprey that turned up at our dugout on October 7 didn't stay long. What the Kingfisher that hung around for several weeks this fall lived on I don't know but I doubt very much if it was fish, and evidently so did that Osprey for the last we saw of him he was heading for the Qu'Appelle, probably Crooked Lake. However, if he'd come in June or early July he could have found fish, albeit small ones, for the children were dipping them out of the ditches on No. 47 all the time. One was even found in a rye field that was being drained.

Yes, it was pretty wet around Grenfell this year and though the Federal Government still hasn't got round to admitting it the Blackcrowned Night Herons that lived and raised young in the vicinity certainly thought is was wet enough for them.

Fish, Herons, Kingfishers and Ospreys-what next? Whales? 